\title{
Long-Term Treatment With Anti-Interleukin 5 Antibodies in a Patient with
}

\section{Chronic Eosinophilic Pneumonia}

\section{SUPPLEMENTARY MATERIAL}

\section{Figure 1 supplementary.}

Chest CT finding of the patient. A: No abnormal findings on October 15, 2015 when the patient visited the hospital first. B: Chest CT examination on June 9, 2016 showing ground-glass attenuations and nodular opacities. C: Chest CT on October 27, 2016 showing no abnormal findings. D: Chest CT on May 24, 2018 after 2-year mepolizumab administration. E: Chest CT on March 14, 2019 when the patient had mild cough attacks showing no abnormal findings. F: Chest CT on August 28, 2019 after 1.25-year benralizumab administration.
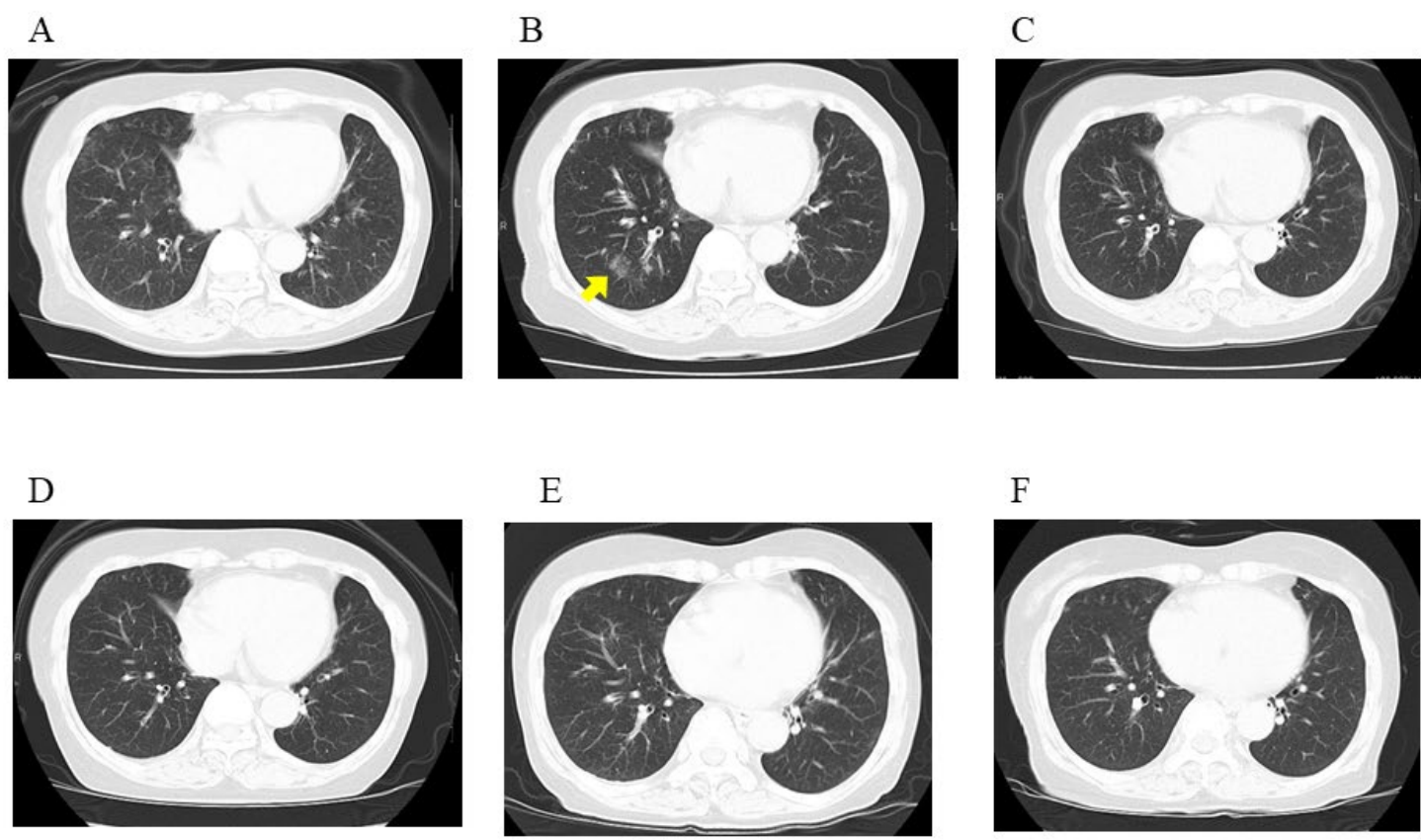